\title{
PENDIDIKAN SEKS DALAM GEREJA SEBAGAI UPAYA PENINGKATAN KUALITAS MORAL REMAJA
}

\author{
Ruth Judica Siahaan \\ (Dosen STT Ekumene Jakarta: Ruth@sttekumene.ac.id)
}

\begin{abstract}
In this study the authors analyzed descriptively the independent variable Moral Quality of Youth and the Sex Education variable in the church. The sampling technique used in this study is saturated sample, which means the technique of determining the sample if all members of the population are used as samples. The results of this study also prove that the dominant indicator in forming the variable Moral Quality Improvement for Youth $(Y)$ is a Significant Definition of Sex Education (X1) at $\alpha \leq 0.05$ by contributing 0.798 times. And the results of the study prove that the dominant aspect in shaping the variable enhancing adolescent moral quality $(Y)$ is an indicator of educational background (X5) significantly at $\alpha \leq 0.05$.
\end{abstract}

Keywords: Sex Education, Church, Moral, Youth

\section{A. PENDAHULUAN}

Di Indonesia pada saat ini ancaman yang paling besar adalah degradasi moral, terutama pada generasi mudanya. Degradasi moral yang terjadi dikalangan remaja merupakan sebuah keprihatinan yang sangat mendalam bagi masyarakat pada saat ini, khususnya pada anak remaja Kristen. Moral adalah cerminan hidup setiap orang. Melihat realitas sekarang ini dengan maraknya tindakan asusila, pencurian, sampai tindakan pembunuhan yang semakin hari semakin meningkat, ini bukanlah hal yang sepele bagi agama dan juga bagi negara.

Tindakan asusila belakangan ini terjadi bukan hanya meliputi anak remaja atau orang dewasa yang menjadi korban, bahkan dalam dunia pendidikan sudah tercemari oleh kejahatan asusila ini. Dimana anak-anak yang seharusnya mendapat pendidikan yang baik untuk membangun negara ini justru menjadi korban dari penyelewengan seks. Itu hanya sebagian kecil yang terlihat dan diangkat oleh publik masih banyak penyelewengan seks yang dialami oleh anak-anak (fedophilia) dan remaja.

Penyelewengan seks bukan hanya berbentuk visual dan fiktif yang berkaitan dengan diri sendiri namun ada juga yang berkaitan dengan orang lain baik sesama jenis maupun lawan jenis bahkan lebih memprihatinkan adalah penyelewengan seks yang dilakukan manusia terhadap binatang (Zoophilia) seperti yang dilakukan oleh Bernard Marshonek, 
seorang warga negara Amerika Serikat, ia melakukan berhubungan seks dengan seekor anjing. ${ }^{1}$ Dari segmen visual ada berbagai bentuknya seperti majalah porno.

Menurut Bram Soei Ndoen dalam buku "The way to reign as Kings in life" mengatakan pornografi yang telah mewabah dikalangan pria telah menjadi industri yang sangat menguntungkan. Tercatat ada 27.560 .000 pria berlangganan majalah porno. Jumlah ini dua kali lipat dari jumlah orang yang berlangganan majalah olahraga. ${ }^{2}$ Belum lagi banyak anak remaja bahkan sampai kepada tingkat pendidikan dasar banyak yang mengakses video porno. Tidak hanya sampai mengakses video porno tersebut, namun mereka juga menjadi pelaku dari video porno tersebut. Banyak hal yang melatar belakangi hal tersebut mulai dari ekonomi yang sulit, pergaulan dengan teman-teman yang salah, keingintahuan mereka untuk mencoba-coba, bahkan pembuktian jati diri yang salah.

Free sex di kalangan masyarakat baik usia muda maupun dewasa/tua terutama di kotakota besar cenderung menjadi budaya atau gaya hidup (Fakta: 80\% mahasiswa di Jogja telah melakukan hubungan seks dan $70 \%$ di antaranya adalah anak SMA dan di Jatinangor ditemukan ribuan kondom ditempat sampah). Hubungan seks tanpa ikatan perkawinan, hubungan seks tanpa perkawinan, hubungan seks usia dini yang berakibat hamil diluar nikah, nilai aborsi yang tinggi, dan perselingkuhan menjadi suatu hal yang semakin lumrah di sebagian masyarakat Indonesia. ${ }^{3}$

Semua hal ini justru mencerminkan bagaimana pendidikan seks yang ada di Indonesia ini lemah bahkan pembicaraan seks antara anak dengan orang tua menjadi sebuah hal yang tabu. Tidak sedikit juga orang tua ketika anak-anaknya bertanya tentang seks, mereka langsung memberhentikan pembicaraannya. Orang tua yang menutupi keingintahuan anaknya sesungguhnya sedang menjadikan anaknya seperti senjata makan tuan yang akan mencelakan dirinya sendiri. Akhirnya mereka mencari tahu kepada sumber yang salah, sehingga mengakibatkan ${ }^{4}$ :

i). Tindakan tanpa tanggung jawab (Anak-anak melihat adegan seks atau penyimpangan seks lainnya, dalam pikiran mereka akan terekam pesan bahwa seks boleh dilakukan kapan saja dan dengan siapa saja).

${ }^{1}$ Melly Febrida, "10 Penyimpangan Seksual Akibat Kelainan,” Liputan 6, last modified 2014, accessed March 8, 2014, https://www.liputan6.com/health/read/2019438/10penyimpangan-seksual-akibat-kelainan. 168.

${ }^{2}$ Soei Bram Ndoen, The Way to Reign As King's In Life (Yogyakarta: Andi, 2013), 2009), 110.

${ }^{3}$ M.John Nainggolan, PAK Dalam Masyarakat Majemuk (Bandung: Bina Media,

${ }^{4}$ Irianto Koes, Seksologi Kesehatan (Bandung: Alfabeta, 2014), 81-82. 
ii). Banyaknya kasus pelecehan seksual (dalam sebuah penelitian terhadap nara pidana yang melakukan pelecehan seksual terhadap anak, $77 \%$ dari mereka melakukannya terhadap anak pria dan $87 \%$ melakukan terhadp anak wanita, mengaku terbiasa menggunakan pornografi sebagai pendorongnya. Dan pornografi mempermudah pelecehan seksual terhadap anak dalam berbagai cara).

iii). Mendorong anak melakukan tindakan seksual terhadap anak lain (dalam sebuah penelitian yang dilakukan oleh Dr. Jenning Bryant terhadap 600 pria dan wanita usia SMP dan dibawahnya di Amerika Serikat, dia menemukan bahwa 91\% pria dan $82 \%$ wanita mengaku telah menonton film porno atau yang berisi kekerasan seksual. Lebih dari $66 \%$ pria dan $40 \%$ wanita dilaporkan ingin mencoba beberapa adegan Sex yang telah ditontonnya. Dan diantara siswa menengah, $31 \%$ pria dan $18 \%$ wanita mengaku benarbenar melakukan adegan dalam film porno itu beberapa hari setelah menontonnya).

iv). Mempengaruhi pembentukan sikap, nilai dan prilaku (Anak menjadi terbayang-bayang mengenai adegan seks yang dilihatnya hingga mempengaruhi tingkah lakunya).

v). Mengganggu jati diri dan perkembangan anak (selama waktu kritis tertentu pada masa kanak-kanak, otak mereka telah terprogram tentang orientasi seksual. Selama periode ini pikiran tersebut membangun jaringan mengenai apa yang merangsang atau menarik seseorang. Jika anak melihat penyimpangan seksual dalam otaknya akan terpatri kejadian tersebut.

Dampak yang ditimbulkan dari penyelewengan seksual anak yang sampai hamil diluar nikah bukan hanya rasa malu oleh anak-anak yang melakukan penyelewengan seks, namun juga rasa malu yang dialami oleh keluarga mereka. Melihat stigma yang ada didalam masyarakat Indonesia sendiri cenderung menghina dan mencacimaki atau menjadi buah bibir dalam pembicaraan sehari-hari. Dalam seluruh aspek kehidupan apalagi seks dunia timur sangat menghormati dan menjunjung sebuah keperawanan atau status gadis dari anak perempuan.

Kerusakan yang dialami oleh anak-anak remaja bahkan dewasa ini adalah mengenai penyelewengan seks terhadap sesama jenis seperti pria dengan pria yang lebih dikenal dengan sebutan homo atau perempuan dengan perempuan yang dikenal dengan lesbi. Bahkan dibeberapa Negara Eropa telah mengesahkan hubungan pria dengan pria bahkan sampai ada undang-undang bahwa gereja harus mengesahkan hubungan sesama jenis ini. Hal ini merupakan gejala yang tidak bisa dibiarkan begitu saja bahkan gejala ini sudah menjadi gaya 
hidup dan trend baru di dalam masyarakat metropolitan termasuk kota Jakarta. Gejala ini dapat dilihat di mall-mall atau tempat-tempat hiburan lainnya.

Hal lain yang bisa terjadi dari pendidikan seks yang tidak diberikan sejak dini adalah transgender yaitu istilah yang digunakan untuk mendeskripsikan orang yang melakukan, merasa, berpikir atau terlihat berbeda dari jenis kelamin yang ditetapkan sejak mereka lahir. Contohnya perpindahan jenis kelamin dari pria ke perempuan seperti Dorce Gamalama, Tata Liem, Oscar Lawalata, Sam Brody, Renaldy, Julia Robert (Baby Wijdaya Nasrun). lkitab sendiri menentang orang yang melakukan penyimpangan seks, kejadian 19:1-29 dalam peristiwa Allah menunggang balikan kota Sodom dan Gomora ini menunjukan bahwa Allah sangat menentang perzinaan. Dalam hukum yang Musa atau dekalog dalam hukum yang ke tujuh, Allah memerintahkan jangan berzinah (Keluaran 20:14). Raja Daud ketika melakukan Perzinaan dalam 2 Samuel 11:4-5 "Sesudah itu Daud menyuruh orang mengambil dia. Perempuan itu datang kepadanya, lalu Daud tidur dengan dia. Perempuan itu baru selesai membersihkan diri dari kenajisannya. Kemudian pulanglah perempuan itu kerumahnya. Lalu mengandunglah perempuan itu dan disuruhnya orang memberitahukan kepada Daud, demikian: “Aku mengandung." Atas dosa tersebut (perzinaan) Allah tidak tinggal diam, Allah menghukum Daud. Bahkan lebih daripada perzinaan secara tubuh saja, Yesus jauh lebih keras melarang sesorang untuk melakukan perzinaan Matius 5:27-28 “Tetapi Aku berkata kepadamu: Setiap orang yang memandang perempuan dan menginginkannya, sudah berzinah di dalam hatinya."

Masa remaja merupakan masa peralihan antara masa kanak-kanak dan masa dewasa, yang dimulai pada saat terjadinya kematangan Sexual yaitu antara usia 11 atau 12 tahun sampai dengan 20 tahun, yaitu menjelang masa dewasa muda. Remaja tidak mempunyai tempat yang jelas, yaitu bahwa mereka tidak termasuk golongan anak-anak tetapi tidak juga termasuk golongan orang dewasa. ${ }^{5}$ Remaja bukan hanya sebagai harapan orangtua tetapi juga menjadi harapan negara dan gereja dimasa yang akan datang.Masa remaja merupakan fase yang indah sekaligus mengkhawatirkan dalam kehidupan manusia.Masa peralihan antara masa kanak-kanak dan dewasa.Sebuah tahapan yang penuh dengan perubahan, baik fisik maupun psikis, yang dihadapi oleh anak-anak. ${ }^{6}$

${ }^{5}$ Ibid., 175.

${ }^{6}$ Farzaneh, Bersahabat Dengan Putri Anda (Jakarta: Pustaka Zahra, 2004), 15. 
Pada awal usia remaja, perjuangan kemandiriannya ditandai dengan perubahan dari sifat tergantung kepada orangtua menjadi tidak tergantung. Dan pada saat ini umumnya remaja sudah tidak tertarik lagi dengan aktifitas bersama yang tua, ia akan mencari figure yang dicintai sebagai pengganti orangtuanya. remaja berusaha melepaskan diri dari lingkungan dan ikatan dengan orangtua karena mereka ingin mencari identitas diri. ${ }^{7}$ Pendidikan seks paling pertama harus diadakan dalam lingkungan keluarga peranan orangtua sangat signifikan dalam membentuk pemahaman tentang seks terhadap anak-anak mereka. Sebab anak adalah titipan dari Allah. Gereja harus turut serta dalam mempersiapkan, mengarahkan, membimbing, dan membekali para remaja baik secara mental, emosional, intelektual, dan spiritual. Dan juga orangtua serta gereja harus memfasilitasi dan melengkapi mereka sehingga mampu hidup mandiri dan bertanggung jawab dalam hidupnya.

Sebuah penelitian menunjukkan bahwa separuh dari remaja putri yang menikah di gereja sudah dalam keadaan hamil. ${ }^{8}$ Hal ini kemungkinan terjadi karena kemerosotan moral yang dialami oleh anak remaja. Selama ini pendidikan agama hanya dijalankan sebagai dogma.Padahal anak-anak dan remaja juga perlu diajak berdialog dan diberikan pemahaman sebagimana mereka harus bersikap dan berprilaku seperti yang seharusnya tercermin di dalam kekristenan. Adapun yang menjadi kemerosatan moral dari generasi muda adalah Memudarnya kualitas keimanan, perkembangan teknologi yang sangat cepat dan pengaruh lingkungan sekitar.

Seks adalah anugerah Tuhan dan kudus. Seks dalam perkawinan diberikan Tuhan bagi suami istri untuk: ${ }^{9}$

i). Menggambarkan betapa mesra, indah, dan manisnya hubungan Kristus dengan mempelainya (Efesus 5:31-32).

ii). Menghasilkan keturunan ilahi (Kejadian 1:28; Maleakhi 2: 15).

iii). Persekutuan dan kesatuan suami istri (Kejadian 2:24).

iv). Pernyataan cinta kasih antara suami dan istri (Kidung Agung 2:24).

v). Sebagai rekreasi, yaitu hubungan biologis yang harus dinikmati oleh pasangan suami istri.

${ }^{7}$ Koes, Seksologi Kesehatan, 178-179.

${ }^{8}$ E.Ray Short, Seks, Pacaran Dan Cinta (Bandung: Yayasan Kalam Hidup, 2002), 95.

\footnotetext{
${ }^{9}$ Ndoen, The Way to Reign As King's In Life, 167.
} 
Bahkan seks sejak mula penciptaan telah diberikan oleh Tuhan untuk melaksanakan perintahnya dalam rangka beranak cucu bertambah banyak dan memenuhi bumi Kejadian 1:28 “Allah memberkati mereka, lalu Allah berfirman kepada mereka: "Beranakcuculah dan bertambah banyak; penuhilah bumi dan taklukkanlah itu, berkuasalah atas ikan-ikan di laut dan burung-burung di udara dan atas segala binatang yang merayap di bumi." Seksualitas bukanlah akibat dosa sebagaimana dinyatakan oleh beberapa orang. Namun kehidupan seksual ini hilang keseimbangan karena dosa, sehingga bukannya membawa manusia pada persekutuan dan kebahagiaan, melainkan sering menyebabkan kejatuhannya. ${ }^{10}$ Istilah untuk hubungan seks sebelum menikah di dalam Alkitab adalah percabulan. Kata itu atau beberapa dari bentuk lain kata itu, digunakan setidak-tidaknya 61 kali. Kata tersebut ada di gunakan dalam kitab Kejadian sampai dengan kitab Wahyu. Di setiap tempat kata ini digunakan, perbuatan ini juga dikutuk dengan keras sebagai suatu jenis dosa yang paling berat. ${ }^{11}$

Sex merupakan masalah yang peka dan pribadi sifatnya. ${ }^{12}$ Pendidikan Seks adalah suatu pengetahuan yang mengajarkan segala sesuatu yang berhubungan dengan jenis kelamin. Bagaimana perkembangan alat kelamin itu pada wanita dan laki-laki serta bagaimana fungsi kelamin sebagai alat reproduksi. ${ }^{13}$ Pendidikan Seks seharusnya diberikan kepada anak-anak yang sudah beranjak dewasa atau remaja, baik melalui pendidikan yang dilakukan secara formal ataupun secara informal. Hal ini sangatlah penting untuk mencegah biasnya mengenai pendidikan Seks maupun pengetahuan tentang kesehatan reproduksi di kalangan remaja.

Berbagai Definisi pendidikan Seks: ${ }^{14}$

i). Pendidikan seks di Negara-negara sekuler menitik beratkan pada perilaku seks yang aman dan sehat dan tak mengajari anak-anak tentang bagaimana caranya untuk menghindari seks bebas. Sehingga tidak bisa mengurangi timbulnya penyakit menular seksual (PMS) dan kehamilan pra nikah.

ii). Pendidikan seks adalah pelakuan sadar dan sistematis di sekolah, keluarga, dan masyarakat untuk menyampaikan proses perkelaminan menurut agama dan yang sudah diterapkan oleh masyarakat. Intinya pendidikan seks tidak boleh bertentangan dengan ajaran agama.

${ }^{10}$ Trobisoh Walter, Liku-Liku Seks Bagian 2 (Jakarta: Yayasan Bina Kasih, n.d.), 13.

${ }^{11}$ Short, Seks, Pacaran Dan Cinta, 82.

${ }^{12}$ Koes, Seksologi Kesehatan, 4.

${ }^{13}$ Ibid., 1.

${ }^{14}$ Ibid., 76. 
iii). Biologi menyebutkan bahwa seks merupakan proses pemaduan dan penggabungan sifatsifat genetic untuk mewariskan ciri-ciri suatu spesies supaya tetap langgeng atau disebut juga dengan reproduksi.

Reproduksi yang memerlukan proses seks dikatakan sebagai reproduksi seksual, sedangkan yang tidak memerlukan proses ini disebut sebagai reproduksi aseksual, reproduksi somatik, atau reproduksi vegatif.

Pendidikan seks haruslah dimulai di rumah oleh orangtua yang mengasihi, karena sesungguhnya model kehidupan seksual ada disana. Tetapi masalahnya ialah bahwa dalam kebanyakan keluarga tidak ada pendidikan seksual. Hal inilah yang menghambat mereka membicarakan mengenai pendidikan seksual dengan anak-anak mereka. ${ }^{15}$ Karena Allah telah menciptakan seksualitas, dan karena Tuhan Yesus tidak pernah menyatakannya najis, maka tidak ada alasan sama sekali untuk malu membicarakannya. Justru perlu dibicarakan. ${ }^{16}$

Anak muda yang mendapatkan pendidikan seks yang baik cenderung untuk menjauhi hubungan seks sebelum menikah daripada orang-orang yang tidak mendapat pendidikan seperti itu. ${ }^{17}$ Dan apabila seorang anak tidak bertanya, carilah cara agar pendidikan seks dapat disampaikan kepada anak. Gereja harus turut campur tangan di dalam memberikan pendidikan seks kepada anak dengan membuat sebuah kurikulum yang dapat menyampaikannya secara jelas, antara lain penciptaan manusia (proses terjadinya pembuahan), perkembangan pria dan wanita secara fisik dan psikis, perilaku seksual, dan kesehatan seksual. ${ }^{18}$

Pendidikan seks tetap menentang sanggama sebelum/di luar perkawinan dan tetap menjunjung tinggi nilai perkawinan, akan tetapi pelaksanaan konkritnya sangat tergantung kepada kondisi masyarakat dan keluarga masing-masing. Inilah yang menyebabkan pendidikan seks sampai sekarang sulit sekali dimasukkan kedalam sebuah pembelajaran. ${ }^{19}$ Anak adalah harta yang paling berharga dibandingkan dengan apapun yang ada di dunia ini. Perasaan dicintai adalah kebutuhan yang sangat mutlak bagi setiap orang, terutama bagi seorang anak. Anak-anak membutuhkan landasan seksual berdasarkan nilai-nilai rohani sebelum mereka diserbu dengan gencar oleh media masa yang mengagungkan nilai-nilai

\footnotetext{
${ }^{15}$ K.Anne Hershberger, Seksualitas Pemberiaan Allah (Jakarta: BPK Gunung Mulia, 2008), 13-14.

${ }^{16}$ Walter, Liku-Liku Seks Bagian 2, 13.

${ }^{17}$ Short, Seks, Pacaran Dan Cinta, 144.

${ }^{18}$ Koes, Seksologi Kesehatan, 104.

${ }^{19}$ Ibid., 3.
} 
hedonism, atau mereka sendiri sulit mengendalikan nafsu mereka. Secara ideal gerejalah yang paling tepat memperagakan, menginterpasikan, dan mempromosikan acuan spiritual mengenai seksualitas. ${ }^{20} \mathrm{Hal}$ ini bertujuan agar anak tidak mendapat informasi yang salah mengenai pengertian apa itu seks.

Dewasa ini Gereja yang ada belum mewujudkan Gereja yang sebenarnya. Gereja belum menjadi apa dia dipanggil dan akan mendapatkan kesempernuaannya hanya di kerajaan Allah. ${ }^{21}$ Gereja dapat memberikan sejumlah pengetahuan dan konseling seksual kepada anak. Namun anak perlu memperoleh penekanan yang lebih kuat dalam nilai-nilai spiritual berhubungan dengan Sexualitas, lebih dari apa yang telah disampaikan kepadanya.

Menurut Pdm. Nurlen Marbun S.PAK Pada tahun 1999 seorang hamba Tuhan, Pdt. Alex Iranata, berkhotbah di sebuah gereja kecil yang bernama GBI (Gereja Bethel Indonesia) jemaat Betlehem yang digembalai oleh bapak Pdt. Paulus Hartan Gunadi . Pada saat yang sama ia menubuatkan bahwa Tuhan akan memakai gerejanya (GBI Betlehem) untuk menjangkau banyak jiwa di daerah sekitar gereja tersebut. Dalam menjangkau banyak jiwa GBI Betlehem menggunakan metode "Prinsip 12" yang melibatkan seluruh hamba Tuhan dan Jemaat berpartisipasi untuk melaksanakan Amanat Agung dengan motto Selamatkan Jiwa Berapapun Harganya. ${ }^{22}$

Dengan motto yang ada di GBI Betlehem Taman Kencana yaitu Selamatkan Jiwa Berapapun Harganya demikian juga penulis mengharapkan bahwa gereja GBI Betlehem Taman Kencana dapat melaksanakan pembinaan kepada kaum remaja/pemuda dengan memberikan sex education. Yang bertujuan agar semua remaja/pemuda GBI Betlehem taman kencana dapat membentengi dirinya dengan menggunakan Firman Tuhan disetiap pergaulan mereka.

\section{B. METODE PENELITIAN}

Penelitian ini bertujuan untuk mengetahui secara empiris serta mendalam pemahaman Pendidikan Seks Dalam Gereja Sebagai Upaya Peningkatan Kualitas Moral Remaja. Secara rinci, penelitian ini bertujuan untuk memperoleh informasi tentang:

1. Menguji pengaruh Pendidikan Seks Dalam Gereja terhadap peningkatan kualitas moral remaja di GBI Betlehem Taman Kencana, Jakarta Barat.

2. Menguji dimensi dan indikator mengenai Pendidikan Seks Dalam Gereja manakah yang paling dipahami oleh Remaja di GBI Betlehem Taman Kencana?

\footnotetext{
${ }^{20}$ Hershberger, Seksualitas Pemberiaan Allah, 14.

${ }^{21}$ H.Thomas Groome, Christian Religious Education (Jakarta: BPK Gunung Mulia, 2010), 182.

22،Hasil Wawancara," 2015.
} 
3. Menguji belakang responden yang manakah yang paling mempengaruhi pemahaman remaja di GBI Betlehem Taman Kencana mengenai Pendidikan Seks dalam Gereja?

Jenis penelitian yang dipakai termasuk dalam penelitian eksplanatori. Penelitian ekplanatori ialah penelitan yang mendalami hasil penelitian ekploratori sebagai bentuk inferensi, sehingga hasil penelitian tidak sekedar memiliki gambaran dan refleksi subjektif, tetapi lebih dari itu. Hasil penelitian eksplanatori diharapkan dapat dijadikan gambaran fungsi managerial dalam rangka melakukan pertumbuhan dan perkembangan atas subjek penelitian.

Adapun langkah-langkah dalam penelitian eksplanatori adalah sebagai berikut: Pertama, melakukan penelitian eksploratori. Penelitan ini dapat berupa studi biblika atau studi eksegese atau pengembangan model atau pengembangan treatment atau pengembangan pola. Pada dasarnya, penelitian ini adalah melakukan kajian yang mendalam terhadap variabel dependent dan atau kajian mendalam atas perlakuan (treatment).

Kedua, melakukan penelitan eksplanatori. Penelitian ini berupa survei yang bersifat korelasional atau dapat pula berbentuk penelitian konfirmatori. Dalam tesis ini, penelitian eksplanatori termasuk survey yang bersifat korelasional. Yang meliputi 1 (satu) variabel bebas (independent) dan 1 (satu) variabel terikat (dependent). Adapun pola hubungan antar variabel seperti gambar berikut ini:

\section{PEMBAHASAN}

Dalam pembahasan ini penulis akan mendeskripsikan teori-teori yang diambil dari bebarapa buku yang berhubungan dengan judul penelitian ini yaitu tentang Pendidikan Seks Dalam Gereja Sebagai Upaya Pencegahan Degradasi Moral dan Peningkatan Kualitas Moral Remaja.

\section{Pengaruh Pendidikan Seks Dalam Gereja Sebagai Upaya Peningkatan Kualitas Moral Remaja}

Pendidikan Seks merupakan hal yang penting, apalagi dengan perkembangan dan perubahan kehidupan dalam masyarakat tertentu, seperti masyarakat kota besar, Metropolitan dan tempat-tempat lain yang mengikuti dinamika perubahan termasuk perubahan dalam teknologi. Oleh karena itu masalah Seks dihubungkan dengan dorongan yang ada akan berkurang intensitasnya. Memberikan pendidikan seks yang benar, bukan berarti mengajari remaja mengenal seks saja. Tapi juga menekankan resiko-resiko yang akan ditanggung dari aktifitas seks yang tidak benar. Gereja janganlah menganggap tabu hal-hal yang merupakan 
fakta kehidupan, seperti membincangkan soal seks dan reproduksi. Akan lebih baik dibina dan dibincangkan di ruang yang benar daripada remaja mencari tahu sendiri dengan cara yang tidak benar dan tak terkontrol.

Pendidikan seks merupakan cara pengajaran atau pendidikan yang dapat menolong setiap remaja untuk menghadapi masalah hidup yang bersumber pada dorongan seksual. Dengan demikian pendidikan seksual ini bermaksud untuk menerangkan segala hal yang berhubungan dengan seks dan Seksualitasdalam bentuk yang wajar. Dan pendidikan seks juga tidak selalu harus menanti sampai timbul pertanyaan dari si anak, melainkan dapat direncanakan oleh orangtua sesuai dengan keadaan dan kebutuhan dari si anak tersebut. Paling tidak sebelum anak masuk masa remaja dimana proses kematangan seks mulai timbul, harus sudah diberikan kepada anak tersebut.

Pendidikan seks sendiri perlu ditanamkan sejak memasuki masa pubertas yakni pada jenjah sekolah menengah pertama (masa remaja). Karena pada masa pubertaslah, kondisi fisik remaja mulai memasuki tahap dewasa, dan akan banyak timbul pertanyaan dalam diri mereka tentang hubungan dengan lawan jenis. dan hal itu perlu dikontrol secara ketat agar tidak berlebihan dan sesuai dengan kondisi mereka saat itu. Dengan diberikannya pendidikan seks bagi remaja diharapkan akan mengurangi keingintahuan yang berlebihan dan dengan berkurangnya keingintahuan ini maka keinginan untuk berpetualangan dalam kegiatan Seks diharapkan berkurang. Moral adalah suatu ketentuan-ketentuan kesusilaan yang mengikat perilaku social manusia untuk terwujudnya dinamisasi kehidupan di dunia, kaidah (normanorma) itu ditetapkan berdasarkan konsesus kolektif, yang pada dasarnya moral diterangkan berdasarkan akal sehat yang objektif. Di dalam moral terdapat perbuatan/tingkah laku/ucapan seseorang dalam menjalankan interaksi dengan manusia. Jika yang dilakukan seseorang itu sesuai dengan norma yang berlaku di masyarakat tersebut dan dapat diterima serta mampu menyenangkan lingkungan masyarakatnya, maka orang itu dapat dikatakan memiliki nilai atau mempunyai moral yang baik, begitu juga sebaliknya. Moral juga dapat diartikan sebagai sikap, perilaku, tindakan, perbuatan yang dilakukan seseorang pada saat mencoba melakukan sesuatu berdasarkan pengalaman, tafsiran, suara hati, dan nasihat.

Degradasi moral remaja merupakan suatu keprihatinan yang sangat mendalam bagi gereja. Dimana tiang-tiang penopang gereja menjadi rapuh karena termakan oleh hancurnya moral. Sedangkan moral merupakan cerminan hidup yang ditunjukkan oleh setiap remaja. Adapun contoh-contoh degradasi moral, yaitu pornografi, narkoba, clubbing, free seks, 
pornografi, pornoakasi, tawuran, berjudi, mencuri, dan lain-lain. Hal-hal tersebut bukanlah yang diingkan oleh Allah, yang Allah inginkan adalah setiap umatnya dapat mencerminkan kehidupannya (terang) yang sesuai dengan kebenaran firman Allah.

Hasil analisis hubungan di sampel antara variabel pendidikan seks (X) dengan Variabel peningkatan kualitas moral remaja (Y) yaitu $\mathrm{r}_{\mathrm{xy}}$ sebesar 0,374 adalah memiliki pengaruh yang rendah. Determinasi varians yang menggambarkan Pendidikan Seks Dalam Gereja (X) terhadap peningkatan kualitas moral remaja di GBI Betlehem Taman Kencana (Y) sebesar 0,140. Artinya sumbangan pendidikan seks dalam gereja (X) dapat meningkatan kualitas moral remaja di GBI Betlehem Taman Kencana (Y) sebesar $14 \%$.

\section{Aspek Dominan Yang Mempengaruhi Peningkatan Kualitas Moral Remaja}

Indikator yang paling dominan dari pendidikan seks dalam gereja sebagai upaya peningkatan kualitas moral remaja adalah Materi Pendidikan Seks. Dalam pendidikan seks dalam gereja sebagai upaya peningkatan kualitas moral remaja terdapat tiga indikator yaitu definisi pendidikan seks, materi pendidikan seks, dan metode penyampaian pendidikan seks. Indikator materi pendidikan seks menjadi indikator yang paling dominan karena hal ini menjadi dasar dalam memberikan pendidikan seks dalam gereja sebagai upaya peningkatan kualitas moral remaja. Pendidikan seks dan Kualitas moral merupakan dua hal yang tidak dapat dipisahkan.

Hasil analisis hubungan di sampel antara indicator Definisi Pendidikan Seks Dalam Gereja $\left(\mathrm{X}_{1}\right)$ dengan Variabel peningkatan kualitas moral remaja (Y) yaitu $\mathrm{r}_{\mathrm{x} 1 \mathrm{y}}$ sebesar 0.587 adalah memiliki pengaruh yang sedang. Determinasi varians yang menggambarkan Definisi Pendidikan Seks Dalam Gereja $\left(\mathrm{X}_{1}\right)$ terhadap peningkatan kualitas moral remaja di GBI Betlehem Taman Kencana (Y) sebesar 0,337. Artinya sumbangan Definisi Pendidikan Seks Dalam Gereja $\left(\mathrm{X}_{1}\right)$ dapat meningkatan kualitas kualitas moral remaja di GBI Betlehem Taman Kencana (Y) sebesar $33 \%$. Hasil analisis hubungan di sampel antara indicator Materi Pendidikan Seks Dalam Gereja $\left(\mathrm{X}_{2}\right)$ dengan Variabel peningkatan kualitas moral remaja (Y) yaitu $\mathrm{r}_{\mathrm{x} 2 \mathrm{y}}$ sebesar 0.757 adalah memiliki pengaruh yang sedang. Determinasi varians yang menggambarkan Materi Pendidikan Seks Dalam Gereja $\left(\mathrm{X}_{2}\right)$ terhadap peningkatan kualitas moral remaja di GBI Betlehem Taman Kencana (Y) sebesar 0,568. Artinya sumbangan Materi Pendidikan Seks Dalam Gereja $\left(\mathrm{X}_{2}\right)$ dapat meningkatan kualitas kualitas moral remaja di GBI Betlehem Taman Kencana (Y) sebesar $56 \%$. Hasil analisis hubungan di sampel antara indicator Metode Penyampaian Pendidikan Seks Dalam Gereja $\left(\mathrm{X}_{3}\right)$ dengan Variabel 
peningkatan kualitas moral remaja $(\mathrm{Y})$ yaitu $\mathrm{r}_{\mathrm{x} 3 \mathrm{y}}$ sebesar 0.563 adalah memiliki pengaruh yang sedang. Determinasi varians yang menggambarkan Metode Penyampaian Pendidikan Seks Dalam Gereja $\left(\mathrm{X}_{3}\right)$ terhadap peningkatan kualitas moral remaja di GBI Betlehem Taman Kencana (Y) sebesar 0,308. Artinya sumbangan Metode Penyampaian Pendidikan Seks Dalam Gereja $\left(\mathrm{X}_{3}\right)$ dapat meningkatan kualitas kualitas moral remaja di GBI Betlehem Taman Kencana (Y) sebesar $30 \%$. Berdasarkan uji regresi sederhana di dapat indikator yang dominan yaitu Materi Pendidikan Seks Dalam Gereja $\left(\mathrm{X}_{2}\right)$. Sedangkan berdasarkan uji Classification and Regression Trees (CRT) didapatkan indikator paling dominan adalah Definisi Pendidikan Seks $\left(\mathrm{X}_{1}\right)$.

\section{Latar Belakang Peningkatan Kualitas Moral Remaja}

Latar belakang remaja mempengaruhi pendidikan seks dalam gereja sebagai upaya pencegahan degradasi moral dan peningkatan kualitas moral. Jemaat yang berjenis kelamin perempuan menunjukkan peninkatan kualitas moral dibandingkan dengan yang berjenis kelamin laki-laki. Kesetiaan beribadah akan membuat remaja semakin memiliki pemahaman yang baik mengenai pendidikan seks yang dapat menjadi "Rambu-Rambu" dalam menjalani kehidupan sehari-hari (pergaulan). Hal ini dikarenakan kesetiaan tersebut membuatnya sering mendengarkan pengajaran firman Tuhan dan Pembinaan yang dilakukan di dalam gereja, baik melalui khotbah dan melalui seminar yang diadakan di gereja yang mendorongnya uuntuk melakukan di dalam kehidupannya.

Latar belakang remaja mempengaruhi pendidikan seks dalam gereja sebagai upaya pencegahan degradasi moral dan peningkatan kualitas moral. Jemaat yang berpendidikan SLTA dan yang berusia 15-18 tahun menunjukkan peninkatan kualitas moral dibandingkan dengan yang berpendidikan SLTP dan yang berusia 11-15 tahun. Semakin dewasa dan banyaknya informasi yang diberikan semakin remaja tersebut matang dan mengerti mengenai hal-hal apa saja yang boleh dilakukan dan yang tidak boleh dilakukan di kehidupan seharihari. Keberadaan yang demikian membuat remaja berusaha untuk hidup dalam kekudusan sebagaimana yang dikehendaki oleh Allah. Dengan demikian diduga bahhwa latar belakang yang paling dominan menentukan pendidikan seks dalam gereja sebagai upaya pencegahan degradasi moral dan peningkatan kualitas moral di Gereja Bethel Indonesia Taman Kencana Jakarta Barat adalah Pendidikan dan Usia. 
Dalam menentukan pengaruh langsung dan tidak langsung terhadap Variabel Peningkatan Kualitas Moral Remaja (Y) atau endogenous variabel yang dominan dibentuk oleh kategori latar belakang $\left(\mathrm{X}_{4-6}\right)$, peneliti menganalisis dengan Classification and Regression Trees (CRT). Peneliti menetapkan Prunning yaitu Depth sebesar 5; Parent sebesar 25; dan Child sebesar 5, pada taraf signifikansi 0,05. Berdasarkan analisis tersebut ditemukan bahwa yang memiliki pengaruh langsung dalam pembentukan Variabel Peningkatan Kualitas Moral Remaja (Y) adalah Indikator Latar Belakang Pendidikan ( $\left.\mathrm{X}_{5}\right)$. Indicator ini mampu memperbaiki 0,237 kondisi Variabel Peningkatan Kualitas Moral Remaja (Y) seperti sekarang secara signifikan pada $\alpha<0,05$. Jika ditelaah secara mendalam, ditemukan juga bahwa Indikator Latar Belakang Pendidikan $\left(\mathrm{X}_{5}\right)$ dibentuk oleh Indikator Usia $\left(\mathrm{X}_{6}\right)$.

\section{KESIMPULAN}

Berdasarkan analisis dari data penelitian maka kebijakan yang dibuat adalah mewujudkan pendidikan seks dalam gereja secara berkala dan efektif. Meningkatkan pendidikan seks dalam gereja sebagai upaya peningkatan kualitas moral di GBI Betlehem Taman Kencana - Jakarta Barat dan dilakukan secara lebih mendalam dengan mengundang pembicara yang ahli di bidang pendidikan seks dalam gereja. Meningkatkan pendidikan seks dalam gereja sebagai upaya peningkatan kualitas moral di GBI Betlehem Taman Kencana Jakarta Barat dan membimbing para Pembina remaja untuk dapat membina dan membekali setiap remaja yang ada dengan membuat kelompok-kelompok kecil untuk selalu mengadakan sharing setelah ibadah. Memberikan informasi kepada setiap jemaat gereja mengenai pendidikan seks baik itu dampak positif ataupun dampak negative dalam memberikan pendidikan seks dalam gereja.

Dalam memberikan pendidikan seks bagi remaja di GBI Betlehem Taman Kencana Jakarta Barat hendaknya gereja membuat seminar secara berkala dan membuat seminar tersebut dengan sekreatif mungkin agar para remaja dapat memhami dengan baik. Sehingga dengan informasi yang jelas maka remaja dapat mengaplikasikannya di kehidupan sehari-hari. Materi pendidikan seks dalam gereja yang diberikan untuk para remaja hendaknya sesuai dengan kebutuhan remaja tersebut (up to date).

Pembina adalah figur yang diteladani dan di dengarkan setiap perkataannya, tetapi perlu diingat bahwa pembina juga merupakan seorang manusia yang bukanlah seorang yang sempurna yang juga memiliki kelemahan, sehingga kadangkala pembina mempunyai 
kesalahan namun haruslah diketahui bahwahal yang baiklah yang harus diikuti dan didengarkan oleh para peserta didik namun setiap yang salah atau negatif dari seorang Pembina tersebut janganlah hendak ditiru. Dan hendaklah apa yang telah diketahui dan telah dipelajari beberapa bulan ini bukan hanya disimpan didalam hidup saja tetapi diaplikasikan didalam kehidupan sehari-hari. Karena dengan menghidupkan firman dan melakukan segala yang Allah kehendaki didalam hidup maka hidup akan berarti dan berkenaan dihadapan Allah.

Banyak diantara beberapa Pembina remaja yang kurang serius dalam menangani permasalahan yang ada, menganggap remeh segala sesuatunya. Sehingga tidak dapat melaksanakan perannya sebagai Pembina remaja dengan maksimal. Menjadi sebagai Pembina remaja bukan hanya sekedar memiliki talenta atau kepintaran, tetapi menjadi seorang Pembina remaja haruslah dapat melaksankan segala sesuatunya dengan menggunakan hati yang tulus sehingga semua yang dilakukannya bukan hanya sekedar melakukan tetapi dia dapat menjawab segala kebutuhan para remaja tersebut.

Seksualitas merupakan pemberiaan dari Allah yang mana pemberian ini diberikan kepada setiap manusia sejak dari dalam kandungan. Pemberiaan seksualitas itu, sama seperti dengan pemberian yang lainnya, yang dimaksudkan untuk memberikan kebahagiaan di dalam kehidupan manusia. Pendidikan Seks telah banyak dikenal orang, tetapi banyak yang belum memahaminya. Ini bisa dimengerti karena norma dan nilai yang berlaku dalam masyarakat Indonesia yang belum memungkinkan untuk membicarakan secara terbuka. Dan pendidikan Seks masih dianggap tabu dan hanya urusan orang dewasa saja. Pendidikan Seks paling pertama harus diadakan dalam lingkungan keluarga peranan orangtua sangat signifikan dalam membentuk pemahaman tentang Seks. 


\section{DAFTAR PUSTAKA}

Farzaneh. Bersahabat Dengan Putri Anda. Jakarta: Pustaka Zahra, 2004.

Febrida, Melly. “10 Penyimpangan Seksual Akibat Kelainan.” Liputan 6. Last modified 2014. Accessed March 8, 2014. https://www.liputan6.com/health/read/2019438/10penyimpangan-seksual-akibat-kelainan.

Groome, H.Thomas. Christian Religious Education. Jakarta: BPK Gunung Mulia, 2010.

Hershberger, K.Anne. Seksualitas Pemberiaan Allah. Jakarta: BPK Gunung Mulia, 2008.

Koes, Irianto. Seksologi Kesehatan. Bandung: Alfabeta, 2014.

Nainggolan, M.John. PAK Dalam Masyarakat Majemuk. Bandung: Bina Media, 2009.

Ndoen, Soei Bram. The Way to Reign As King's In Life. Yogyakarta: Andi, 2013.

Short, E.Ray. Seks, Pacaran Dan Cinta. Bandung: Yayasan Kalam Hidup, 2002.

Walter, Trobisoh. Liku-Liku Seks Bagian 2. Jakarta: Yayasan Bina Kasih, n.d.

"Hasil Wawancara," 2015. 